\title{
On Italian mobilities and ecological fretwork
}

\author{
Stephanie Malia Hom* \\ French and Italian Department, University of California, Santa Barbara, USA
}

(Received 23 February 2021; final version accepted 23 February 2021)

\begin{abstract}
This invited commentary explores the ecological fretwork binding people and nature, and, specifically, how Italy and Italianness serve as critical frames for envisioning an environmental history of migration. It examines how each contribution in this special issue adds rigorous archival research to the growing body of academic literature on Italy and the environmental humanities. It also comments on the future research directions, which are connected to this emerging history. Situating these contributions in the wider context of climate change and planetary transformation, this article illuminates how mobilities, understood as an Italian phenomenon, have shaped the globe on a scale previously unknown.
\end{abstract}

Keywords: migration; Italy; environmental humanities; climate change.

A chorus of living wood sings to the woman: If your mind were only a slightly greener thing, we'd drown you in meaning.

The pine she leans against says: Listen. There's something you need to hear. (Richard Powers, The Overstory, p.4)

'Listen, there's something you need to hear', opens The Overstory $(2018,4)$, Richard Powers' monumental work of environmental fiction, which weaves together the life stories of people with the age-old lives of trees. The story plays out along twinned timelines - one fast (humans), one slow (trees) - but both seemingly resigned to one collective fate, the devastation of the environment, and with it, humanity: all because we cannot, will not, listen to the 'chorus of living wood' willing to drown us in meaning. Powers' book has been hailed as the great American eco-novel but, more than that, it is a call to listen and observe the impacts that we, as humans, have unleashed upon on the planet. What we extract from the environment matters, whether by means of logging, oil and gas, overfishing, industrial agriculture, and more, as does what we expel into and onto the land, water, and air, everything from toxic waste and microplastics to untreated sewage and chemical fertilizers. Our impact goes beyond even the bounds of our planet, with more than 100 million pieces of space debris encasing the earth like a metallic sarcophagus.

The Overstory is a call to attend to our 'socio-natures', that is, the vital connections between people and nature. For ours is an existence inextricably tied to the forests, oceans, plains, pampas, mountains, serras, deserts, or put simply, the environment writ large. Indeed, the coronavirus pandemic that spread across the globe in 2020 shows clearly how intertwined we are with nature, how our encroachment upon wildlife habitats led to zoonotic spillover and thus became a catastrophic threat to human existence. Yet The Overstory, steeped as it is in grief and shame around human

\footnotetext{
*Email: smh@ucsb.edu
}

(C) The Author(s), 2021. Published by Cambridge University Press on behalf of the Association for the Study of Modern Italy. This is an Open Access article, distributed under the terms of the Creative Commons Attribution licence (http://creativecommons.org/licenses/by/4.0/), which permits unrestricted re-use, distribution, and reproduction in any medium, provided the original work is properly cited. 
greed, carelessness, and indifference towards our planet, ends with a gesture towards a feeling that the future is not yet foreclosed. The book concludes with one of the central characters, Nick, building an art project in a forest: he spells out the word 'still' from downed logs and forest detritus on a scale large enough that the word can be seen from space. By holding still, the text asserts, we might achieve just the slightest shift in consciousness, a shift that would afford us even 'the mildest form of reconciliation to the rest of the living world' (Hamner 2018) and inspire in us appreciation and gratitude for what we have been given, a world of meaning imparted by a chorus of living wood.

In this special issue of Modern Italy dedicated to 'Environment and Italianness: Socio-Natures on the Move', the authors compel us to explore the ecological fretwork binding people and nature and, specifically, how Italy and Italianness serve as critical frames for envisioning an environmental history of migration, along with a new understanding of the variegated mobilities that said history involves. An unspoken yet animating concern implicit in all of the contributions is also that of the Italian imprint on climate change. Each article traces out the long-lasting impact of human presence on a given landscape - from the city of Kerch on the Black Sea in Crimea, to the Argentinian pampas, to the wine-growing highlands of Brazil, to the rural South in the USA, to agricultural homesteads in Libya. All these contributions document the inscription of Italianness onto landscapes, and at the same time, the erasure of the landscapes, both human and natural, that came before them. In time, too, these 'Italian' landscapes become erased, their histories forgotten, and their imprints left on both environment and society, sometimes in devastating ways, as with clear-cut logging in Brazil or mass animal die-offs in Libya (see De Majo and Peruchi Moretto as well as Biasillo). Situating these contributions in a wider context of global warming and planetary transformation illuminates how mobilities understood as Italian have shaped the globe on a scale previously unknown.

At the same time, this special issue adds rigorous archival research to the growing body of academic literature on Italy and the environmental humanities (Iovino 2016; Iovino, Cesaretti, and Past 2018; Past 2019; Seger 2015). The authors anchor the transformation of socio-natures in the historical record, using primary sources found in local and national archives as well as personal letters, newspaper and magazine articles, architectural blueprints, land-use plans, oral history interviews, among other documents. Together, we glean from their contributions a picture of Italianness on the move constituted by socioecological praxis: the imprimatur of 'Italy' impressed on everything from mineral water production in Crimea (see Rojas Gomez) to artisanal cheesemaking in Argentina's pampa gringa (see Valisena and Canovi). At the same time, we also see how such praxis reconfigures Italianness from the outside in. For example, one need only to think of the wine industry in California. In the late nineteenth and early twentieth centuries, Italian immigrants navigated fraught racial politics as well as Prohibition in the US to monopolise the socioecological praxis of winemaking, branding it as 'Italian' while at the same time strengthening regional identities, in particular, piemontesità (Piedmontese-ness) (Cinotto 2012).

In such ways, differential notions of 'Italy' and Italianness went mobile and became affixed in varying degrees to movements of people, objects, and ideas. Some forms of Italianness found more purchase than others, as in the example of California winemaking, while other forms of Italianness were invented, managed, and manipulated by the state, as was the case with settler colonists in Fascist colonial Libya who purportedly embodied 'la più grande Italia' (greater Italy). With more than 13 million people leaving Italy between 1880 and 1915, Italians constituted 'the largest emigration from any country in recorded world history' (Choate 2008, 1) and this migration was, and still is, linked fundamentally to Italy's colonial project in two distinct ways. First, in the late nineteenth century, the colonies in Africa and the Aegean were intended to stem the flows of emigrants leaving Italy for the Americas and the Antipodes by diverting them into new territories that 
were considered external to, but nonetheless still within, the fold of the Italian nation-state (Ben-Ghiat and Hom 2016, 4-9). Second, in the early twenty-first century, the practices of sequestration and detention perfected under the Italian colonial regime have resurfaced with amplified force in Italy's contemporary migration crisis. In both moments, more than a century apart, the control of mobility proved to be the fulcrum of empire (Hom 2019, 4-7).

In this issue, Roberta Biasillo's examination of the Fascist agricultural enterprise in Libya between 1922 and 1943 adds a new dimension to these imperial power dynamics by showing how the Italian colonial regime mobilised plants, seeds, and animals to 'materially correct local ecological conditions'. Imported flora and fauna became as important as those charged with their care, Italian settler colonists, for they would be the means through which to prove Libya a fertile and productive colony, worthy of reclaiming its status as the granary of ancient Rome and validating the Fascist regime's hereditary claim to the Roman empire. Biasillo deftly shows how 'ecological control paired with social control', which, in colonial Libya, it might be argued, went even one step further: it was not simply control, but rather outright eradication - ecocide paired with genocide. The full-scale annihilation of nomadic livestock, the poisoning of wells, the dispossession and destruction of local property and gardens, the partitioning of land with barbed-wire fences, and the incarceration of roughly one hundred thousand Bedouin in concentration camps where almost half of those who entered died, all amounted to devastation of the region's biota and its inhabitants. One wonders, too, if this wholesale ruination under the Italian colonial regime underwrote subsequent patterns of ecological damage, migration, and exploitation in Libya, especially those that took hold in the 1960s with the discovery of oil, yet another after-effect of Italy's long colonial twilight (Ballinger 2016).

In his article, Gilberto Mazzoli expertly complicates the idea of settler colonialism by detailing how Italian and American diplomats created policies that shunted newly arrived Italian immigrants to the rural US South during the age of mass migrations (circa 1880-1915). There, they were pressured to create agricultural colonies and work farmland in places like North Carolina, Virginia, Tennessee, and Texas. Away from the overcrowded tenements of East Coast cities, where they were often stereotyped as ignorant and unskilled (despite an extensive praxis of urban gardening), Italians would be transformed into 'shrewd, self-respecting, independent farmers and citizens' when relocated to rural communities, according to the 1911 Dillingham Commission Report. Italians, then, would become desirable subjects, that is, the 'right kind' of immigrants, by way of urban gardening and rural agriculture. Mazzoli briefly alludes to US racial relations when describing how Italian agricultural colonisation would have increased the white population in the South, an insight that would be a rich area of inquiry to develop with further research. Unlike the 'in-between' racial space that Italian immigrants exploited in California's winemaking industry (Cinotto 2012; Monserrati 2021), racial hierarchies were black-and-white in the American South, codified by Jim Crow, and violently policed and reinforced by the powers that be (Wilkerson 2020). Exactly how Italian immigrants navigated postbellum racial hierarchies and the tacit caste system in the South, their whiteness often being contextual, fluid, and contested elsewhere in the US, would make for a fascinating study.

In that same era of mass migration, Claudio De Majo and Samira Peruchi Moretto train their lens on Italian immigrants who settled in a different south, that is, the Rio Grande do Sul state of Brazil, where they transformed the landscape through logging and viticulture, and, at the same time, forged a new identity as Italian colonos (settlers). De Majo and Peruchi Moretto trace the intertwined evolution between colonos and the mountainous upland region known as the Serra Gaúcha. At first, Italian immigrants set up a profitable logging business there, clearcutting their way through the forest until the region was on the brink of ecological crisis. To borrow the 
words of Richard Powers, they had been 'plant-blind' (Powers 2018, 114). But this blindness would not last for long, insofar as Italian colonos quickly came to understand that plants would be crucial to creating a sustainable livelihood. Indeed, it might be said that a single seed transformed the landscape into a renewable resource: the Isabella grape. Imported from North America, this species of grape thrived in the harsh climate of the Serra Gaúcha and enabled Italian colonos to develop the region into Brazil's largest winemaking industry. In so doing, De Majo and Moretto note that colonos, via the grape, created a prototypical Mediterranean landscape while simultaneously forging for themselves a 'hybrid eco-cultural identity'.

What connects the experiences of the Italian colonos in the Serra Gaúcha with those of Italian immigrants in south-west Texas (see Mazzoli) as well as Italian colonists in Libya (see Biasillo) is the presence of indigenous peoples, who, per the top-down policies of the state (e.g. Brazil, US, Italy), needed to be subjugated, concentrated, and controlled. Whether the semi-nomadic Bedouin in Libya, the Kaingang and Xokleng tribes in Brazil, or the Cherokee and other tribes that ended up in Texas after the Indian Removal Act of 1930, these indigenous peoples served as absolute others against which Italianness, too, became inscribed, with Italian immigrants becoming inserted into a position above caste members of an even lower rank. Further study of the relationship between Italianness and indigeneity would most certainly deepen our perspectives on both Italian mobilities and the environmental history of migration.

Heloisa Rojas Gomez offers an original case study of another faraway south, one that has received little attention in the context of Italian migrations: the city of Kerch in eastern Crimea. Rojas Gomez focuses on the Italian immigrants who settled in Kerch primarily from the 1820s to the 1900s, a timeframe that includes the expansion of the Russian empire to the south and the east, ending with the Bolshevik Revolution. Rojas Gomez tracks transnational circuits of migration between Italy and Russia that were highly localised, focusing on the distinct ties between Kerch and two small towns in Puglia, Trani and Bisceglie. These migratory circuits were born of well-worn trade routes between the Adriatic Sea and the Black Sea. According to Rojas Gomez, Tsarist Russia strongly encouraged connections with Italy, for they strengthened an idea of empire orientated toward the Mediterranean, thus symbolically linking the Russian empire to both antiquity and civilisation. Put another way, immigrants from the Italian South would have a 'civilising effect' on Kerch through socioecological practices like farming, fishing, gardening, and mineral water production as well as direct intervention in the built environment with the construction of neighbourhoods, gardens, and orchards. Although the Bolshevik Revolution effectively put an end to the Italian presence in Kerch, Rojas Gomez notes that the Italian micro-footprint is still there. Of particular interest for future research would be the exploration of how food and tourism, two of Italy's foremost industries, persist in this micro-footprint; in particular, the affiliated legacies of Italian mineral water production and wellness (benessere) tourism.

In their article, Antonio Canovi and Daniele Valisena skilfully demonstrate Italianness to be as composite, fluid, and mobile as the plainscapes they compare in Italy and Argentina; respectively, the pianura padana (Po River basin) and the pampa húmeda ('humid plain', later to become known as the pampa gringa, or 'gringo plain'). This conversion from pampa húmeda to pampa gringa is owed, in large part, to the labour of Italian migrants hailing from the Po Valley who successfully channeled their 'millennia-long hydraulic culture' and 'broadly-shared amphibious memory' into transforming the plains into a fertile agriculture zone. Put another way, Italian immigrants in the pampas helped to catalyse a change in the landscape that was also reflected in the terminology: the plains went from being identified by a climactic property (húmedo) to being linked instead with a socio-cultural attribute (gringo, meaning 'foreigner'). Along with other immigrants from England, Switzerland, and Germany, Italians on the move helped to shape the 
socio-nature of the pampas, inscribing along the way expressions of Italianness onto the landscape, such as alfalfa cultivation and local community dairy farms specialising in artisanal cheese production.

In terms of future research, it would be interesting to expand the scope of these plainscapes in order to map transnational circuits of padana identity and know-how. It was no coincidence that Italians from the Veneto and Emilia-Romagna were prioritised to settle the newly drained plains of the Agro Pontino during the Fascist regime, a clear effort to put to use padano hydraulic heritage and amphibious memory in service to the bonifica integrale (land reclamation), the largest internal colonisation effort in modern European history (Caprotti 2007). They were also handpicked to settle and cultivate the high plains of Cyrenaica as part of the settler initiative in Italian colonial Libya (Cresti 2011) as well as in Italian East Africa (Taddia 2005, 211-13). A critical line of inquiry, then, would chart the ways in which Italianness integrates with padanità (Padano-ness) to highlight their combined influence on the environmental history of migration (Crainz 1994, 3-18; Nani 2015).

Knitted into all of these articles - sometimes explicitly, often implicitly - is another cultural imaginary that has informed, and still continues to shape, Italianness and Italy on the move: the Mediterranean. In places like the Serra Gaúcha, northern California, and eastern Crimea, Italian immigrants turned this cultural imaginary into an ecological reality, effectively mobilising the Mediterranean to help marshal the landscape in service to their socioeconomic needs. Put another way, they tapped into the imperial impulse of the Mediterranean, and the histories of power endemic to it, which has been the critical understory to Italy's nation-making project from the outset (Fogu 2020). Italianness and Mediterraneanness exist as twinned imaginaries - one territorial, one pelagic - that together have served to circumscribe and de-territorialise 'Italy' at the same time. The vital connections between people and nature, our socio-natures, have existed in symbiosis with these imaginaries, and the contributions to this special issue have provided us with the overstory to help us begin to understand the world of meaning imparted to us by migrating people, plants, animals, and more; they help us to become, again in the words of Richard Powers, 'slightly greener' so that we may truly listen to the 'chorus of living wood' as well as the rest of the planet that is our home.

\section{References}

Ballinger, P. 2016. 'Colonial Twilight: Italian Settlers and the Long Decolonization of Libya'. Journal of Contemporary History 51(4): 813-38.

Ben-Ghiat, R. and S. M. Hom. 2016. 'Introduction'. In Italian Mobilities, edited by R. Ben-Ghiat and S. M. Hom, 1-19. London: Routledge.

Caprotti, F. 2007. Mussolini's Cities: Internal Colonialism in Italy, 1930-1939. Amherst, NY: Cambria Press.

Choate, M. I. 2008. Emigrant Nation: The Making of Italy Abroad. Cambridge, MA: Harvard University Press.

Cinotto, S. 2012. Soft Soil, Black Grapes: The Birth of Italian Winemaking in California. New York: New York University Press.

Crainz, G. 1994. Padania. Il mondo dei braccianti dall'Ottocento alla fuga delle campagne. Rome: Donzelli.

Cresti, F. 2011. Non desiderare la terra d'altri. La colonizzazione italiana in Libia. Rome: Carocci.

Fogu, C. 2020. The Fishing Net and the Spider Web: Mediterranean Imaginaries and the Making of Italians. Cham, Switzerland: Palgrave Macmillan.

Hamner, E. 2018. 'Here's to Unsuicide: An Interview with Richard Powers'. Los Angeles Review of Books, 7 April. https://lareviewofbooks.org/article/heres-to-unsuicide-an-interview-with-richard-powers/ (accessed 13 February 2021). 
Hom, S. M. 2019. Empire's Mobius Strip: Historical Echoes in Italy's Crisis of Migration and Detention. Ithaca, NY: Cornell University Press.

Iovino, S. 2016. Ecocriticism and Italy: Ecology, Resistance, and Liberation. London: Bloomsbury Academic Press.

Iovino, S., E. Cesaretti and E. Past, eds. 2018. Italy and the Environmental Humanities: Landscapes, Natures, Ecologies. Charlottesville, VA: University of Virginia Press.

Monserrati, M. 2021. 'Transcultural Landscapes: Situating Italian Migration in California during the Construction of its Mediterranean-like Landscape'. Paper presented at MLA Convention, Transnational Italian Studies Working Group (January 8).

Nani, M. 2015. 'Bonifica e mobilità: esplorazioni sul caso ferrarese (1872-1900)'. Popolazione e storia 16 (1): 81-99.

Past, E. 2019. Italian Ecocinema Beyond the Human. Bloomington, IN: Indiana University Press.

Powers, R. 2018. The Overstory: A Novel. New York: W.W. Norton.

Seger, M. 2015. Landscapes in Between: Environmental Change in Modern Italian Literature and Film. Toronto: University of Toronto Press.

Taddia, I. 2005. 'Italian Memories/African Memories of Colonialism'. In Italian Colonialism, edited by R. Ben-Ghiat and M. Fuller, 209-19. New York: Palgrave Macmillan.

Wilkerson, I. 2020. Caste: The Origins of our Discontents. New York: Random House.

\section{Italian summary}

Questo commento finale, scritto dall'autrice su invito dei curatori del volume, illustra l'intarsio ecologico che lega esseri umani e natura. In particolare, mostra come l'Italia e il concetto di italianità svolgano un ruolo critico nell'immaginare una storia ambientale delle migrazioni. Il presente testo evidenzia come ogni saggio di questo numero monografico fornisca una nuova base documentaria, archivistica e non, per alimentare il crescente interesse dimostrato dalle environmental humanities nei confronti dell'Italia. L'autrice, inoltra, discute possibili sviluppi futuri delle ricerche qui presentate e inserisce il connubio Italianità-ambiente, in accezine globale, nei contesti attuali del cambiamento climatico e delle trasfrormazioni ecologiche che avvengono su scala planetaria. 